\title{
Changes in the immune system in experimental acanthamoebiasis in immunocompetent and immunosuppressed hosts
}

Natalia Łanocha-Arendarczyk', Agnieszka Kolasa-Wołosiuk², Iwona Wojciechowska-Koszko³, Karolina Kot ${ }^{1}$, Paulina Roszkowska ${ }^{3}$, Barbara Krasnodębska-Szponder ${ }^{3}$, Edyta Paczkowska ${ }^{4}$, Bogusław Machaliński ${ }^{4}$, Karolina Łuczkowska ${ }^{4}$, Barbara Wiszniewska ${ }^{2}$ and Danuta Kosik-Bogacka ${ }^{1 *}$

\begin{abstract}
Background: Acanthamoebiasis is most often found in patients with immune deficiency, with infections facilitated by the intake of immunosuppressive drugs. The host immune response to Acanthamoeba spp. infection is poorly understood. Thus, in this study, we aimed to examine the course of Acanthamoeba spp. infection taking into account the host's immunological status, including assessment of the hematological parameters, cytokine analysis, immunophenotypic changes in spleen populations, and histological spleen changes, which could help clarify some aspects of the immune response to acanthamoebiasis. In our experimental study, we used Acanthamoeba strain AM 22 isolated from the bronchoaspirate of a patient with acute myeloid leukaemia (AML) and atypical pneumonia symptoms.

Results: Acanthamoeba spp. affected the hematological parameters in immunocompetent and immunosuppressed mice and induced a change in spleen weight during infection. Moreover, analysis of anti-inflammatory (IL-4 and IL-10) and proinflammatory (IL-17A and IFN- $-\gamma$ ) cytokines produced by splenocytes stimulated with concanavalin A demonstrated that Acanthamoeba spp. induced a selective Th1, Th2 and Th17 response at later stages of the infection in immunocompetent hosts. In the case of hosts with low immunity, Acanthamoeba elicited robust Th1 cell-mediated immunity without the participation of Th17. We observed suppression of CD8+ and CD4+ T lymphocytes and CD3+CD4-CD8- double-negative (DN) T lymphocyte populations in the beginning, and in the case of CD3+/CD4+/CD8+ double-positive (DP) T cells in the final phase of Acanthamoeba spp. infection in hosts with low immunity. Also, CD4+T lymphocytes and CD3+/CD4+ and CD3+/CD8+ lymphocyte counts during each stage of acanthamoebiasis were shown to be upregulated.

Conclusions: We demonstrated that analysis of the immune response and pathogenesis mechanisms of clinical isolates of Acanthamoeba spp. in an animal model not only has purely cognitive significance but above all, may help in the development of effective methods of pharmacological therapy especially in patients with low immunity.
\end{abstract}

Keywords: Acanthamoeba spp., Immunological status, Immunophenotype

\footnotetext{
*Correspondence: kodan@pum.edu.pl

'Department of Biology and Medical Parasitology, Pomeranian Medical

University in Szczecin, 70-204 Szczecin, Poland

Full list of author information is available at the end of the article
}

(c) The Author(s). 2018 Open Access This article is distributed under the terms of the Creative Commons Attribution 4.0 International License (http://creativecommons.org/licenses/by/4.0/), which permits unrestricted use, distribution, and reproduction in any medium, provided you give appropriate credit to the original author(s) and the source, provide a link to the Creative Commons license, and indicate if changes were made. The Creative Commons Public Domain Dedication waiver (http://creativecommons.org/publicdomain/zero/1.0/) applies to the data made available in this article, unless otherwise stated. 


\section{Background}

Acanthamoebiasis is an opportunistic invasion caused by protozoans of the genus Acanthamoeba and is much more frequently noted in patients with immune deficiency, such as immunosuppressed patients following solid organ and bone marrow transplants and patients with HIV/AIDS [1]. Also, at risk are individuals with lymphoproliferative or hematologic disorders, diabetes mellitus, pneumonitis, renal failure, hepatic diseases, and gamma-globulinemia [1-3].

In immunosuppressed hosts, amoeba infections change the host-parasite relationships from oligosymptomatic and/or asymptomatic forms to acute disseminated parasitic infections affecting many organs, ultimately leading to the death of the host [4]. The widespread presence of Acanthamoeba makes them a significant threat to human health. After penetrating the central nervous system, lungs, cornea or human skin, they can cause granulomatous encephalitis (GAE), pneumonia (Acanthamoeba pneumonia), Acanthamoeba keratitis (AK), and cutaneous acanthamoebiasis (CA) $[5,6]$. Several hundred cases of amoebic brain infections have been reported worldwide, with the first identified human case of GAE occurring in an immunosuppressed patient with Hodgkin's disease [7]. The host immune response to Acanthamoeba spp. infection is poorly understood, even though $50-90 \%$ of people are known to be seropositive [8]. Immunocompetent patients are more likely to have brain invasions and secondary cutaneous lesions, while patients with low immunity more frequently have isolated primary cutaneous skin infections [9]. Immunocompetent patients develop a granulomatous reaction, while in immunosuppressed individuals, granuloma formation is weak, especially in HIV patients $[10,11]$.

Experimental and in vitro studies suggest the induction of innate and adaptive immune responses by Acanthamoeba spp., although there is a high discrepancy in the data $[1,12]$. Brain Acanthamoeba spp. infection is a result of the host immune response and is most probably composed of CD4+ and CD8+ T cells, B lymphocytes, plasma cells and macrophages [2]. Deficiency in cell-mediated immunity is an important risk factor for GAE [13]. The factors that limit the activity of this protozoan parasite include neutrophils, macrophages and microglial cells. Moreover, their anti-parasitic effects are mediated in part by respiratory burst and nitric oxide under the influence of pro-inflammatory cytokines including interleukin-1, TNF and/or IFN [1, 10, 14, 15]. An in vitro study by Cano et al. [12] showed that ocular Acanthamoeba keratitis induced the proinflammatory macrophage phenotype characterised by the production of IL-12 and IL-6. Little is known about the pathogenesis of Acanthamoeba pneumonia including the complexity of immunological mechanisms. We do know that these parasites cause inflammation, e.g. in the lungs, with the coexistence of primary lesions in other organs and systems. Here, we focused on the immune system in both immunocompetent and in immunosuppressed hosts as a suitable animal model to study acanthamoebiasis in humans. This is the first experimental model induced by Acanthamoeba spp. isolated from the bronchoaspirate of a patient with acute myeloid leukaemia with atypical pneumonia symptoms [5]. Previously, we observed that this strain (AM 22) was pneumophilic, which may affect the expression and activity of cyclooxygenase-1 (COX-1) and cyclooxygenase-2 (COX-2), resulting in altered levels of their main products, prostaglandins $\left(\mathrm{PGE}_{2}\right)$ and thromboxane $\mathrm{B}_{2}\left(\mathrm{TXB}_{2}\right)$, in the lungs of immunocompetent or immunosuppressed hosts [16]. Thus, in this study, we aimed to examine the course of Acanthamoeba spp. infection taking into account the host's immunological status including assessment of the hematological parameters , cytokine analysis, immunophenotypic changes in spleen populations and histological spleen changes which could help clarify some aspects of the immune response to acanthamoebiasis.

\section{Methods}

\section{Strain}

The AM 22 strain isolated from bronchoaspirate of a 53-year-old male with acute septic shock was used in this study. The patient was in the blast crisis of acute myeloid leukemia and additionally was diagnosed with pneumonia. Based on analysis of a PCR-amplified 850 bp Ami fragment of $18 \mathrm{~S}$ rRNA-gene the AM 22 strain was identified as Acanthamoeba genotype T16 [5]. Amoeba culture was grown on media with non-nutrient agar (NN Agar) coated with inactivated Escherichia coli bacteria, and incubated at $37{ }^{\circ} \mathrm{C}$ for $72 \mathrm{~h}$. After the proliferation of Acanthamoeba, the trophozoites were washed with a sterile isotonic solution of $0.9 \% \mathrm{NaCl}$ and prepared for intranasal inoculation of the test animals.

\section{Animal model}

Our experimental model of acanthamoebiasis involved BALB/c mice $(n=96)$ aged about $6-10$ weeks, divided into four groups: (i) Group C: immunocompetent animals not infected with Acanthamoeba spp., $(n=18)$; (ii) Group A: immunocompetent animals infected with Acanthamoeba spp., $(n=30)$; (iii) Group CS: immunosuppressed animals not infected by Acanthamoeba spp.; immunosuppression induced by methylprednisolone (MPS) ( $n=18)$; and (iv) Group AS: immunosuppressed animals infected by Acanthamoeba spp.; immunosuppression induced by MPS $(n=30)$.

For four days $(-4,-3,-2,-1,0)$ AS and CS animals were intraperitoneally administered $0.22 \mathrm{mg}$ MPS (10 $\mathrm{mg} / \mathrm{kg}$ ) (Solu-Medrol, Pfizer, Puurs, Belgium, Europe 
MA EEIG), a steroid with immunosuppressive properties according to the methodology described by Markovitz et al. [17]. Such an algorithm made it possible to create an experimental model of tests under in vivo conditions, similar to patients with a reduced level of immunity. MPS is used in the treatment of acute organ rejection episodes. Animals from groups A and AS were given $3 \mu \mathrm{l}$ of a suspension of Acanthamoeba trophozoites containing 10-20 thousand of the amoebae counted in Bürker chamber, intranasally. Mice from the $\mathrm{C}$ and CS groups received $3 \mu \mathrm{l}$ of $0.9 \% \mathrm{NaCl}$ intranasally. The animals were dissected at 8,16 and 24 days after infection (dpi), depending on the onset of symptoms after intraperitoneal administration of sodium pentobarbital $(2 \mathrm{ml} / \mathrm{kg})$ (Euthasol vet, FATRO, Raamsdonksveer, The Netherlands). During the dissection, tissues and organs (including the spleen) were collected for immunological and histological analysis and adequately secured. The collected spleens were weighed.

\section{Laboratory blood test}

Whole blood from the heart of the mice was sampled using the $1.2 \mathrm{ml}$ blood collection system $\mathrm{S}$ Monovette (SARSTEDT AG\&Co, Nümbrecht, Germany) containing K3EDTA as an anticoagulant. The study was carried out at the Clinical Central Laboratory in Szczecin. By means of a laser hematology analyzer, Sysmex XS-800i (Sysmex-Europe, Norderstedt, Germany), 11 parameters were measured in each sample: white blood cell count (WBC), number and percentage of lymphocytes (LYM), number and percentage of neutrophils (NEU), number and percentage of monocytes (MONO), number and percentage of eosinophils (EOS), number and percentage of basophils (BASO), red blood cell count (RBC), haemoglobin (HGB), hematocrit (HCT), and platelet count (PLT), as described by Kosik-Bogacka et al. [18].

\section{Flow cytometric immunophenotyping}

Immunophenotypic analysis of splenocytes by flow cytometry was undertaken as described by Kabat-Koperska et al. [19], and this test was only performed for immunosuppressed animals, including AS and CS groups. Spleens were collected during the section of the animals, then placed in Hank's $1 \times$ balanced salt solutions, cut into pieces, pressed through nylon to sterile Roswell Park Memorial Institute medium (Sigma-Aldrich, St. Louis, USA ) containing phenol red and L-glutamine. The liquid was transferred to a centrifuge tube containing the same volume of RPMI 1640 medium, then centrifuged (2000 $\times g$ for $20 \mathrm{~min}$ at room temperature). The middle cloud layer was placed in lymphocytes isolation medium and centrifuged $(1000 \times g$ for $10 \mathrm{~min}$ at room temperature). The following monoclonal antibodies were used $(\mathrm{mAb})$ : $\mathrm{PE}$ Hamster Anti-Mouse CD3e (Clone 145-2C11), FITC Rat Anti-Mouse CD4 (Clone RM4-5), APC Rat Anti-Mouse CD8a (Clone 53-6.7) (BD Biosciences,San Jose, USA). Samples were subjected to acquisition using an LRS II flow cytometer (Becton Dickinsson, San Jose, CA, USA) and FacsDiva version 6.2 software (BD Biosciences). Appropriate isotype antibodies were used as controls (FITC Rat IgG2a к Isotype Control, PE Hamster IgG1 к Isotype Control, APC Rat IgG2a к Isotype Control) (BD Biosciences). Typically, 30,000 events were acquired to determine the percentage of the examined sub-population within the spleen cell population. Analysis of sub-populations of lymphocytes in the spleen was based on the presence of CD3, CD4, and CD8 antigens on the cell surface (Fig. 1).
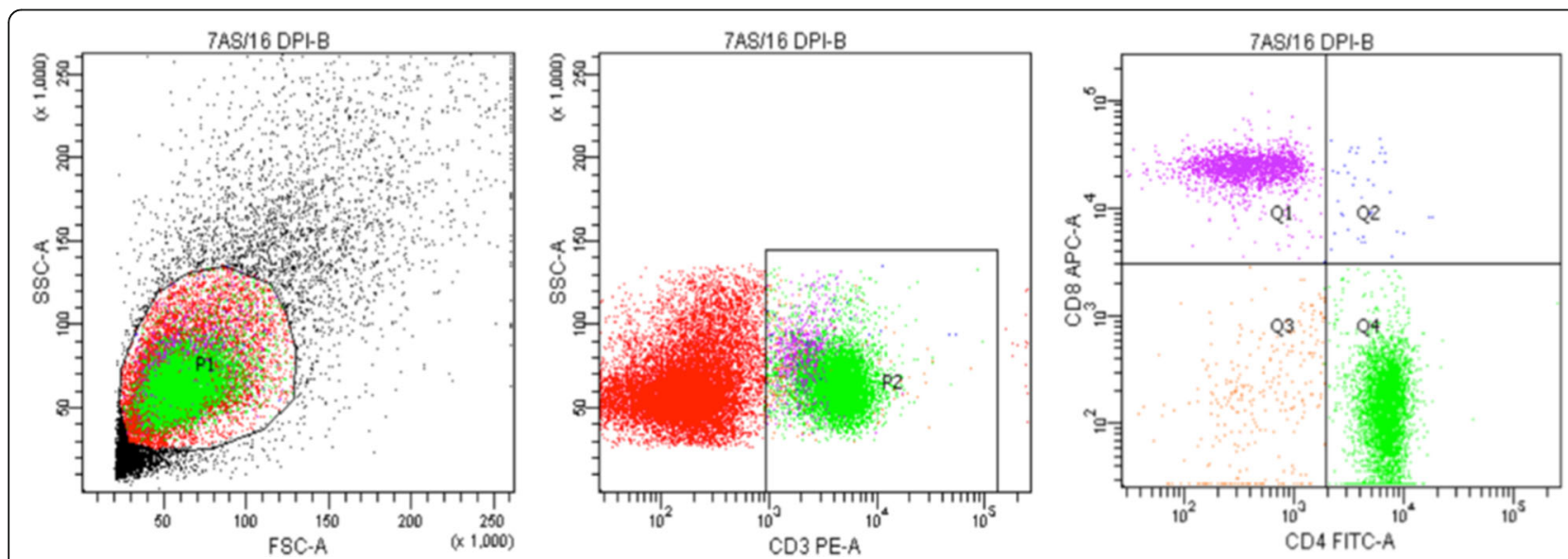

Fig. 1 An example of a gating strategy used to identify sub-populations of T lymphocytes in the spleen using antigens CD3, CD4, CD8. Dot-plots show spleen cell gating on the side scatter (SSC) and forward scatter (FSC) (gate P1). Events contained by gate P2 were characterised by the presence on the surface of the CD3 antigen (CD3+ lymphocytes). Cells positive for the CD3 marker were further divided based on their expression of CD4 and CD8 antigen. Sub-populations of lymphocytes such as CD3+ (P2), CD3+/CD4+ (quadrant Q2+Q4), CD3+/CD8+ (Q1+Q2), CD3+/CD4+/CD8+ (Q2), CD3 +/CD4-/CD8- (Q3) were analysed using this strategy 


\section{Cytokine assays}

Cell suspensions at a density of $2 \times 10^{6}$ lymphocytes were placed in wells, $0.5 \mathrm{ml}$ of cell suspension in $1 \mathrm{ml}$ of incubation medium: RPMI, $10 \%$ bovine serum, $50 \mu \mathrm{g} / \mathrm{ml}$ of gentamycin and increasing amounts of concanavalin $\mathrm{A}$ (ConA, $0 \mu \mathrm{g} / \mathrm{ml} ; 5 \mu \mathrm{g} / \mathrm{ml}$ ) we estimated the functional response to this mitogen [19]. Incubation of lymphocytes in the well plates was carried out at $37^{\circ} \mathrm{C}$ for $72 \mathrm{~h}$ under an atmosphere containing $5 \% \mathrm{CO}_{2}$. After incubation, the cell suspensions were centrifuged at $1000 \times g$ for $10 \mathrm{~min}$. The concentrations of cytokines (IL-4, IL-10, IL-17, INF- $\gamma$ ) were determined in the culture supernatants using enzyme-linked immunoassays according to the manufacturer's recommendations (BD Biosciences, BD OptEIA Set Mouse IL-4, IL-10, INF- $\gamma$ for IL-4, IL-10, INF- $\gamma$, respectively; IL-17A [homodimer] ELISA Ready-SET-GO for IL-17 (Affymetrix, Santa Clara, CA, USA). Results for each cytokine were expressed in $\mu \mathrm{g} / \mathrm{ml}$. Standard curves were derived from the cytokine standards supplied with the kit.

\section{Histology spleen examination}

Spleen tissues were fixed in 10\% formalin for at least 24 $\mathrm{h}$ and embedded in paraffin. Paraffin slides $(3 \mu \mathrm{m})$ of the mice spleen were stained with hematoxylin-eosin, and a general histological examination was undertaken.

\section{Statistical analysis}

The analysis used Statistica 10.0 software (StatSoft). The arithmetic means (AM), standard deviations of the AM (SD), and medians (Med) were calculated for each studied group. In order to determine compliance with the expected normal distribution of results, a Kolmogorov-Smirnov test with Lilliefors correction $(P<0.05)$ was used. Non-parametric tests (Kruskal-Wallis and Mann-Whitney U-test) were used as data deviated from a normal distribution. Differences between groups were analysed with the Mann-Whitney U-test for comparison of 2 groups and the Kruskal-Wallis test for comparison of 4 groups. The significance level was $P<0.05$.

\section{Results}

\section{Spleen weight}

We observed a significantly lower total spleen weight in the Acanthamoeba spp. infected groups (immunocompetent and immunosuppressed) compared to control groups (C and CS) (Table 1). The weight of the spleen at 8 dpi was significantly lower in the group A than in the control (Mann-Whitney U-test, $U=30, P=0.05$ ), also at $16 \mathrm{dpi}$ lower in the group $\mathrm{A}$ than in the group $\mathrm{C}$ (Mann-Whitney U-test, $U=41, P=0.02$ ) and lower in the group AS than in the group CS (Mann-Whitney U-test, $U=42.5, P=0.02$ ). At $24 \mathrm{dpi}$ we observed significant differences between infected groups with different immunological status (A vs AS, Mann-Whitney U-test, $U=72, P=0.02$ ) (Table 1 ).

\section{Haematology results}

We noted statistically significant differences in examined basic hematological parameters between control groups

Table 1 Spleen weight (g) of male mice in control and Acanthamoeba spp. infected groups after 8, 16 and 24 days post-infection (dpi)

\begin{tabular}{|c|c|c|c|c|c|c|}
\hline Parameter/group & & $\begin{array}{l}\text { Group A } \\
(n=10)\end{array}$ & $\begin{array}{l}\text { Group C } \\
(n=6)\end{array}$ & $\begin{array}{l}\text { Group AS } \\
(n=10)\end{array}$ & $\begin{array}{l}\text { Group CS } \\
(n=6)\end{array}$ & Kruskal-Wallis test \\
\hline \multirow[t]{3}{*}{ Total spleen weight } & $A M \pm S D$ & $0.06 \pm 0.03^{\mathrm{a}}$ & $0.07 \pm 0.008^{a}$ & $0.08 \pm 0.06^{b}$ & $0.10 \pm 0.01^{b}$ & \multirow{3}{*}{$\begin{array}{l}H=29.81 \\
d f=2 \\
P=0.001\end{array}$} \\
\hline & Median & 0.07 & 0.07 & 0.1 & 0.1 & \\
\hline & Range & $0.02-0.15$ & $0.06-0.09$ & $0.01-0.20$ & $0.1-0.15$ & \\
\hline \multirow[t]{3}{*}{8 dpi } & $\mathrm{AM} \pm \mathrm{SD}$ & $0.05 \pm 0.02^{c}$ & $0.07 \pm 0.01^{c}$ & $0.11 \pm 0.04$ & $0.10 \pm 0.02$ & \multirow{3}{*}{$\begin{array}{l}H=22.78 \\
d f=3 \\
P=0.001\end{array}$} \\
\hline & Median & 0.06 & 0.07 & 0.10 & 0.10 & \\
\hline & Range & $0.03-0.07$ & $0.06-0.08$ & $0.1-0.2$ & $0.1-0.15$ & \\
\hline \multirow[t]{3}{*}{$16 \mathrm{dpi}$} & $\mathrm{AM} \pm \mathrm{SD}$ & $0.05 \pm 0.02^{d}$ & $0.07 \pm 0.01^{d}$ & $0.04 \pm 0.06^{e}$ & $0.10 \pm 0.0^{e}$ & \multirow{3}{*}{$\begin{array}{l}H=15.36 \\
d f=3 \\
P=0.01\end{array}$} \\
\hline & Median & 0.06 & 0.07 & 0.01 & 0.10 & \\
\hline & Range & $0.02-0.07$ & $0.06-0.08$ & $0.01-0.20$ & $0.10-0.10$ & \\
\hline \multirow[t]{3}{*}{$24 \mathrm{dpi}$} & $\mathrm{AM} \pm \mathrm{SD}$ & $0.08 \pm 0.03^{f}$ & $0.08 \pm 0.01$ & $0.09 \pm 0.03^{f}$ & $0.10 \pm 0.0$ & \multirow{3}{*}{$\begin{array}{l}H=13.79 \\
d f=3 \\
P=0.01\end{array}$} \\
\hline & Median & 0.08 & 0.08 & 0.10 & 0.10 & \\
\hline & Range & $0.05-0.15$ & $0.07-0.09$ & $0.01-0.10$ & $0.10-0.10$ & \\
\hline
\end{tabular}

${ }^{a} P \leq 0.03$ for the significance of difference A vs C (Mann-Whitney U-test, $U=311$ ),

${ }^{\mathrm{b}} P \leq 0.04$ for the significance of difference AS vs CS (Mann-Whitney U-test, $U=297$ )

${ }^{c} P \leq 0.05$ for the significance of difference $A$ vs $C$ (Mann-Whitney U-test, $U=30$ )

${ }^{\mathrm{d}} P \leq 0.02$ for the significance of difference A vs $C$ (Mann-Whitney U-test, $U=41$ )

${ }^{\mathrm{e}} P \leq 0.02$ for the significance of difference AS vs CS (Mann-Whitney U-test, $U=42.5$ )

${ }^{\mathrm{f}} P \leq 0.02$ for the significance of difference A vs AS (Mann-Whitney $U$-test, $U=72$ )

Abbreviations: Group A, immunocompetent infected group; Group C, immunocompetent control group; Group AS immunosuppressed infected group; Group CS, immunosuppressed non-infected group; AM, arithmetic mean; SD, standard deviation 
(C and CS) and Acanthamoeba spp.-infected immunocompetent mice (A) and infected mice with low immunity (AS) (Table 2). We observed higher lymphocyte count in the group AS than in the group CS $(0.92 \mathrm{G} / \mathrm{l} v \mathrm{~s}$ $0.65 \mathrm{G} / \mathrm{l}$, Mann-Whitney U-test, $U=78, P=0.01$ ). There were significantly lower monocyte counts in the group A than in the group AS $(0.11 \mathrm{G} / \mathrm{l} v s 0.36 \mathrm{G} / \mathrm{l}$, Mann-Whitney U-test, $U=51, P=0.02$ ) and higher in the group AS than in the group CS $(0.36 \mathrm{G} / \mathrm{l}$ vs $0.06 \mathrm{G} / \mathrm{l}$, Mann-Whitney U-test, $U=57.5, P=0.03)$. The basophile count was significantly higher in the group AS, than in the group CS $(0.23 \mathrm{G} / \mathrm{l}$ vs $0.05 \mathrm{G} / \mathrm{l}$, Mann-Whitney U-test, $U=76, P=0.01)$. We found higher platelet count in the group $\mathrm{A}$ than in the group C (633.3 G/l vs $481.4 \mathrm{G} / \mathrm{l}$, Mann-Whitney U-test, $U=$ $52, P=0.05)($ Table 2).

\section{Cytokine assays}

Analysis of cytokine profile after incubation of the lymphocytes from the spleen with increasing doses of concanavalin A (ConA) (0 and $5 \mu \mathrm{g} / \mathrm{ml})$ found higher

Table 2 Hematology results of Acanthamoeba spp. infected immunocompetent, immunosuppressed and control groups

\begin{tabular}{|c|c|c|c|c|c|c|}
\hline Parameter/group & & $\begin{array}{l}\text { Group A } \\
(n=10)\end{array}$ & $\begin{array}{l}\text { Group C } \\
(n=10)\end{array}$ & $\begin{array}{l}\text { Group AS } \\
(n=10)\end{array}$ & $\begin{array}{l}\text { Group CS } \\
(n=10)\end{array}$ & Kruskal-Wallis test \\
\hline \multirow[t]{3}{*}{ WBC (G/l) } & $\mathrm{AM} \pm \mathrm{SD}$ & $1.83 \pm 0.55$ & $1.38 \pm 0.33$ & $1.57 \pm 0.85$ & $1.92 \pm 1.05$ & \multirow{3}{*}{$\begin{array}{l}H=2.03 \\
d f=3 \\
P=0.57\end{array}$} \\
\hline & Median & 1.89 & 1.27 & 1.53 & 1.89 & \\
\hline & Range & $1.14-2.74$ & $1.12-1.85$ & $0.63-3.41$ & $0.40-3.60$ & \\
\hline \multirow[t]{3}{*}{ LYM (G/l) } & $A M \pm S D$ & $1.11 \pm 0.27$ & $1.11 \pm 0.25$ & $0.92 \pm 0.56^{a}$ & $0.65 \pm 0.38^{a}$ & \multirow{3}{*}{$\begin{array}{l}H=12.04 \\
d f=3 \\
P=0.04\end{array}$} \\
\hline & Median & 1.08 & 1.05 & 0.84 & 0.55 & \\
\hline & Range & $0.78-1.51$ & $0.89-1.47$ & $0.00-1.68$ & $0.32-1.08$ & \\
\hline \multirow[t]{3}{*}{ NEU (G/l) } & $A M \pm S D$ & $0.01 \pm 0.01$ & $0.02 \pm 0.01$ & $0.03 \pm 0.07$ & $0.01 \pm 0.01$ & \multirow{3}{*}{$\begin{array}{l}H=3.32 \\
d f=3 \\
P=0.47\end{array}$} \\
\hline & Median & 0.01 & 0.01 & 0.01 & 0.01 & \\
\hline & Range & $0.00-0.01$ & $0.00-0.02$ & $0.00-0.24$ & $0.00-0.02$ & \\
\hline \multirow[t]{3}{*}{ MONO (G/l) } & $\mathrm{AM} \pm \mathrm{SD}$ & $0.11 \pm 0.12^{b}$ & $0.08 \pm 0.13$ & $0.36 \pm 0.87^{b, c}$ & $0.06 \pm 0.10^{c}$ & \multirow{3}{*}{$\begin{array}{l}H=6.48 \\
d f=3 \\
P=0.02\end{array}$} \\
\hline & Median & 0.04 & 0.02 & 0.05 & 0.05 & \\
\hline & Range & $0.01-0.27$ & $0.00-0.27$ & $0.00-2.80$ & $0.00-0.30$ & \\
\hline \multirow[t]{3}{*}{$\operatorname{EOS}(\mathrm{G} / \mathrm{l})$} & $\mathrm{AM} \pm \mathrm{SD}$ & $0.02 \pm 0.01$ & & $0.06 \pm 0.19$ & $0.17 \pm 0.28$ & \multirow{3}{*}{$\begin{array}{l}H=0.71 \\
d f=3 \\
P=0.86\end{array}$} \\
\hline & Median & 0.01 & & 0.03 & 0.01 & \\
\hline & Range & $0.00-0.02$ & 0 & $0.01-0.60$ & $0.01-0.50$ & \\
\hline \multirow[t]{3}{*}{ BASO (G/l) } & $\mathrm{AM} \pm \mathrm{SD}$ & $0.27 \pm 0.13$ & $0.13 \pm 0.07$ & $0.23 \pm 0.17^{d}$ & $0.05 \pm 0.08^{d}$ & \multirow{3}{*}{$\begin{array}{l}H=7.75 \\
d f=3 \\
P=0.01\end{array}$} \\
\hline & Median & 0.23 & 0.13 & 0.24 & 0.02 & \\
\hline & Range & $0.14-0.49$ & $0.09-0.49$ & $0.01-0.61$ & $0.01-0.20$ & \\
\hline \multirow[t]{3}{*}{ RBC (T/I) } & $\mathrm{AM} \pm \mathrm{SD}$ & $9.30 \pm 0.37$ & $9.64 \pm 0.10$ & $9.18 \pm 0.42$ & $8.47 \pm 3.19$ & \multirow{3}{*}{$\begin{array}{l}H=4.41 \\
d f=3 \\
P=0.22\end{array}$} \\
\hline & Median & 9.34 & 9.62 & 9.24 & 9.59 & \\
\hline & Range & $8.7-9.7$ & $9.5-9.8$ & $8.3-9.68$ & $9.02-10.1$ & \\
\hline \multirow[t]{3}{*}{$\mathrm{HGB}(\mathrm{mmol} / \mathrm{l})$} & $A M \pm S D$ & $9.01 \pm 0.34$ & $9.37 \pm 0.15$ & $8.91 \pm 0.33$ & $9.16 \pm 0.30$ & \multirow{3}{*}{$\begin{array}{l}H=4.92 \\
d f=3 \\
P=0.17\end{array}$} \\
\hline & Median & 9.0 & 9.04 & 9.0 & 9.27 & \\
\hline & Range & $8.6-9.6$ & $9.2-9.5$ & $8.30-9.2$ & $8.70-9.6$ & \\
\hline \multirow[t]{3}{*}{$\mathrm{HCT}(\mathrm{L} / \mathrm{l})$} & $\mathrm{AM} \pm \mathrm{SD}$ & $0.41 \pm 0.009$ & $0.43 \pm 0.01$ & $0.41 \pm 0.02$ & $0.42 \pm 0.01$ & \multirow{3}{*}{$\begin{array}{l}H=2.02 \\
d f=3 \\
P=0.57\end{array}$} \\
\hline & Median & 0.41 & 0.43 & 0.41 & 0.41 & \\
\hline & Range & $0.40-0.43$ & $0.41-0.43$ & $0.38-0.43$ & $0.40-0.43$ & \\
\hline \multirow[t]{3}{*}{ PLT (G/l) } & $\mathrm{AM} \pm \mathrm{SD}$ & $633.3 \pm 176.6^{e}$ & $481.4 \pm 277.6^{e}$ & $866.8 \pm 60.3$ & $912.0 \pm 109.3$ & \multirow{3}{*}{$\begin{array}{l}H=4.60 \\
d f=3 \\
P=0.02\end{array}$} \\
\hline & Median & 646.5 & 355.0 & 889.5 & 880.0 & \\
\hline & Range & $432.0-932.0$ & $204.0-808.0$ & $746.0-950.0$ & $803.0-1120.0$ & \\
\hline
\end{tabular}

${ }^{a} P \leq 0.01$ for the significance of difference AS vs CS (Mann-Whitney U-test, $U=78$ )

${ }^{\mathrm{b}} P \leq 0.02$ for the significance of difference A vs AS (Mann-Whitney $U$-test, $U=51$ )

${ }^{c} P \leq 0.03$ for the significance of difference AS vs CS (Mann-Whitney U-test, $U=57.5$ )

${ }^{d} P \leq 0.01$ for the significance of difference AS vs CS (Mann-Whitney U-test, $U=76$ )

${ }^{\mathrm{e}} P \leq 0.05$ for the significance of difference A vs $C$ (Mann-Whitney U-test, $U=52$ )

Abbreviations: Group A, immunocompetent infected group; Group C, immunocompetent control group; Group AS immunosuppressed infected group; Group CS, immunosuppressed non-infected group; G, giga; AM, arithmetic mean; SD, standard deviation 
level of IL-4 (anti-inflammatory cytokine) after administration of a higher dose of ConA $(5 \mu \mathrm{g} / \mathrm{ml})$ at 16 dpi in the group A compared to AS (Mann-Whitney U-test, $U=22.5, P=0.02$ ). We observed an increased level of IL-10 (anti-inflammatory cytokine) with a higher dose of Con A in both infected groups (A and $\mathrm{AS}$ ) at $16 \mathrm{dpi}$ (Mann-Whitney U-test; group A $v s \mathrm{C}$ : $U=22, P=0.05$; AS vs CS: $U=25, P=0.01$; A vs AS: $U=16, P=0.01)$. There were significantly higher levels of IL-17A (proinflammatory cytokine) with a higher dose of Con A at 16 dpi in group A compared to group C (Mann-Whitney U-test, $U=22.5, P=$ 0.02 ) and with a lower dose of ConA at $24 \mathrm{dpi}$ in group A vs C (Mann-Whitney U-test, $U=13.5, P=$ 0.05). We noted decreased level of IFN- $\gamma$ (proinflammatory cytokine) with a higher dose of ConA in infected immunocompetent group (A) compared to infected immunosuppressed group (AS) at $24 \mathrm{dpi}$ (Mann-Whitney U-test, $U=11, P=0.05$ ) (Table 3).

\section{Immunophenotyping results}

Immunophenotyping analysis of splenocytes by flow cytometry was only performed for immunosuppressed animals including AS and CS groups. After splenocytes flow cytometry analysis we observed increased CD3 $+/ \mathrm{CD} 4+$ lymphocyte counts in the group AS at $24 \mathrm{dpi}$ (Mann-Whitney U-test, $U=21, P=0.05$ ) and increased CD3+/CD8+ lymphocyte counts in the group AS at 16 dpi (Mann-Whitney U-test, $U=25, P=0.01$ ). We noted decreased populations of double negative cells (CD3 $+/ C D 4-/ C D 8-)$ at 8 dpi in the group AS (Mann-Whitney U-test, $U=24, P=0.02$ ) and increased populations of double positive cells $(\mathrm{CD} 3+/ \mathrm{CD} 4+/ \mathrm{CD} 8+)$ at $24 \mathrm{dpi}$ in the group AS (Mann-Whitney U-test, $U=19, P=0.03$ ) (Table 4). In addition, the percentage of $\mathrm{CD} 3+\mathrm{T}$ cells, CD4+ T cells and CD8+ T cells, the CD4+ / CD8+ cell ratio and the CD4-/CD8- cell population ratio were determined. We observed decreased CD3+ lymphocyte counts in Acanthamoeba spp.-infected groups at $8 \mathrm{dpi}$ (Mann-Whitney U-test, $U=23, P=0.04$ ), but increased at $24 \mathrm{dpi}$ (Mann-Whitney U-test, $U=22, P=0.05$ ). We noted increased CD4+ (Mann-Whitney U-test, $U=25, P$ $=0.01$ ) and decreased CD8+ lymphocyte counts (Mann-Whitney U-test, $U=25, P=0.05$ ) in the group AS at 8 dpi. There was significantly lower CD4-/CD8- lymphocyte ratio counts in the group AS compared with the group CS (Mann-Whitney U-test, $U=22, P=0.05$ ) at 8 dpi (Table 5).

\section{Histology of the spleen}

Figure 2a shows a typical representative histological image of a control mice spleen, with white pulp (WP) consisting of lymphatic nodules with a central artery envelope by PALS, and red pulp (RP) containing venous sinuses and splenic cords. Histology of the spleen after immunosuppressive treatment (Fig. 2b) did not change significantly, although the marginal zone (MZ) was more evident and thicker than in control animals (Fig. 2a). The number and size of lymphatic nodules and structure of the red pulp were very close to that observed in the control mice (Fig. 2a, b). The organs from groups $\mathrm{C}$ and CS were compact and enveloped by a thin connective tissue capsule that sent very delicate septa into the spleen parenchyma. After Acanthamoeba spp. infection (Fig. 3a-f), the observed splenomegaly corresponded with looseness and fragility of the splenic parenchyma. At the beginning of the second week of infection $(8 \mathrm{dpi})$, both in suppressant-treated and control mice (Fig. 3a, d) hyperplasia of the white pulp was observed, and the follicular structure was distorted. In both groups of infected animals (A, AS) the subcapsular area was loose or highly lymphoid infiltrated (yellow or white asterisks, respectively); in the red pulp of these mice, many lymphocytes also occurred. The histological image of the spleen and morphometric measurements showed a decrease in WP/RP ratio at $16 \mathrm{dpi}$ and an increase at 24 dpi in Acanthamoeba spp. infection (Fig. 3c, e and d, f, respectively). In the amoeba infected and immunosuppressed mice the marginal zone was also more evident (Fig. 3b, c, e, f) than in the control mice (Fig. 2a), which could suggest an increase in the number of unique subset of non-circulating IgM+/IgD- B-cells of the marginal zone, opposite to IgM+/IgD+follicular B-cells [20].

\section{Discussion}

The course, pathogenesis and clinical picture of a free-living Acanthamoeba infection is unclear in both immunocompetent and immunosuppressed hosts. In this experimental model, we assessed the impact of the clinical strain AM 22 of Acanthamoeba spp. isolated from a patient with low immunity and with atypical pneumonia symptoms, on changes in the immune system in mice depending on the host's immune status. Immunosuppression at both humoral or cellular levels had different consequences for the host depending on the magnitude and may alter the range of parasites to which the host is susceptible [4].

We noticed a reduction in total spleen mass in Acanthamoeba spp.-infected groups (with normal and low immunity) compared to control mice. When analysing acanthamoebiasis during the period of infection, the spleen mass was greater in immunocompetent Acanthamoeba spp. infected mice at $24 \mathrm{dpi}$ and the weight of this organ decreased at $16 \mathrm{dpi}$ in immunosuppressed infected mice. Likewise, Machado et al. [21], in a Leishmania chagasi experimental model, observed a decrease in spleen weight in steroid-immunosuppressed mice. The change in mass of organs located in the peritoneal 
Table 3 Cytokine profile after incubation of lymphocytes from the spleen with different doses of concanavalin A, ConA (0 $\mu \mathrm{g} / \mathrm{ml} ; 5$ $\mu \mathrm{g} / \mathrm{ml})$

\begin{tabular}{|c|c|c|c|c|c|c|}
\hline Parameter/group & & $\begin{array}{l}\text { Group A } \\
(n=10)\end{array}$ & $\begin{array}{l}\text { Group C } \\
(n=6)\end{array}$ & $\begin{array}{l}\text { Group AS } \\
(n=10)\end{array}$ & $\begin{array}{l}\text { Group CS } \\
(n=6)\end{array}$ & Kruskal-Wallis test \\
\hline \multicolumn{7}{|l|}{ IL-4 } \\
\hline \multirow[t]{2}{*}{8 dpi } & ConAO & 0 & 0 & 0 & 0 & $P=1.0$ \\
\hline & ConA5 & $0.52 \pm 4.33$ & $0.26 \pm 0.59$ & 0 & 0 & $\begin{array}{l}H=2.16 \\
d f=3 \\
P=0.54\end{array}$ \\
\hline \multirow[t]{2}{*}{$16 \mathrm{dpi}$} & ConAO & 0 & 0 & 0 & $1.94 \pm 4.33$ & $\begin{array}{l}H=3.18 \\
d f=3 \\
P=0.39\end{array}$ \\
\hline & ConA5 & $50.35 \pm 51.75^{a}$ & 0 & $0^{a}$ & 0 & $\begin{array}{l}H=11.22 \\
d f=3 \\
P=0.002\end{array}$ \\
\hline \multirow[t]{2}{*}{24 dpi } & ConAO & 0 & 0 & $1.28 \pm 2.86$ & 0 & $\begin{array}{l}H=3.00 \\
d f=3 \\
P=0.31\end{array}$ \\
\hline & ConA5 & $1.19 \pm 2.67$ & $0.66 \pm 1.47$ & 0 & 0 & $\begin{array}{l}H=21.00 \\
d f=3 \\
P=0.54\end{array}$ \\
\hline \multicolumn{7}{|l|}{ IL-10 } \\
\hline \multirow[t]{2}{*}{8 dpi } & ConAO & $84.63 \pm 46.72$ & $149.98 \pm 128.88$ & $83.06 \pm 37.32$ & $58.90 \pm 26.14$ & $\begin{array}{l}H=3.94 \\
d f=3 \\
P=0.27\end{array}$ \\
\hline & ConA5 & $168.43 \pm 180.88$ & $212.92 \pm 180.20$ & $139.47 \pm 125.42$ & $86.16 \pm 12.56$ & $\begin{array}{l}H=4.07 \\
d f=3 \\
P=0.25\end{array}$ \\
\hline \multirow[t]{2}{*}{$16 \mathrm{dpi}$} & ConAO & $128.27 \pm 65.83$ & $78.98 \pm 58.82$ & $78.60 \pm 46.47$ & $69.07 \pm 15.19$ & $\begin{array}{l}H=4.62 \\
d f=3 \\
P=0.34\end{array}$ \\
\hline & ConA5 & $511.09 \pm 40.41^{b, c}$ & $67.42 \pm 16.98^{b}$ & $276.18 \pm 224.72^{c, d}$ & $81.01 \pm 19.34^{d}$ & $\begin{array}{l}H=10.30 \\
d f=3 \\
P=0.01\end{array}$ \\
\hline \multirow[t]{2}{*}{$24 \mathrm{dpi}$} & ConAO & $14.94 \pm 33.40$ & $19.99 \pm 99.96$ & 0 & 0 & $\begin{array}{l}H=2.16 \\
d f=3 \\
P=0.55\end{array}$ \\
\hline & ConA5 & $82.13 \pm 82.73$ & $36.54 \pm 74.12$ & 0 & $230.67 \pm 515.76$ & $\begin{array}{l}H=3.73 \\
d f=3 \\
P=0.29\end{array}$ \\
\hline \multicolumn{7}{|l|}{ IL-17 A } \\
\hline \multirow[t]{2}{*}{8 dpi } & ConAO & 0 & 0 & 0 & 0 & $P=1.0$ \\
\hline & ConA5 & $13.86 \pm 30.98$ & 0 & 0 & 0 & $\begin{array}{l}H=3.00 \\
d f=3 \\
P=0.39\end{array}$ \\
\hline \multirow[t]{2}{*}{$16 \mathrm{dpi}$} & ConAO & 0 & 0 & 0 & $0.75 \pm 1.68$ & $\begin{array}{l}H=4.00 \\
d f=3 \\
P=0.56\end{array}$ \\
\hline & ConA5 & $78.60 \pm 55.28^{e}$ & $0^{e}$ & 0 & $5.24 \pm 7.29$ & $\begin{array}{l}H=11.22 \\
d f=3 \\
P=0.01\end{array}$ \\
\hline \multirow[t]{2}{*}{$24 \mathrm{dpi}$} & ConA0 & $9.97 \pm 13.97^{f}$ & $2.05 \pm 1.54^{f}$ & 0 & 0 & $\begin{array}{l}H=8.44 \\
d f=3 \\
P=0.04\end{array}$ \\
\hline & ConA5 & $13.27 \pm 16.80$ & $1.81 \pm 2.06$ & $32.85 \pm 37.08$ & $38.77 \pm 52.46$ & $\begin{array}{l}H=2.60 \\
d f=3 \\
P=0.45\end{array}$ \\
\hline
\end{tabular}


Table 3 Cytokine profile after incubation of lymphocytes from the spleen with different doses of concanavalin A, ConA (0 $\mu \mathrm{g} / \mathrm{ml} ; 5$ $\mu \mathrm{g} / \mathrm{ml}$ ) (Continued)

\begin{tabular}{|c|c|c|c|c|c|c|}
\hline Parameter/group & & $\begin{array}{l}\text { Group A } \\
(n=10)\end{array}$ & $\begin{array}{l}\text { Group C } \\
(n=6)\end{array}$ & $\begin{array}{l}\text { Group AS } \\
(n=10)\end{array}$ & $\begin{array}{l}\text { Group CS } \\
(n=6)\end{array}$ & Kruskal-Wallis test \\
\hline \multicolumn{7}{|l|}{ IFN- $\gamma$} \\
\hline \multirow[t]{2}{*}{$8 \mathrm{dpi}$} & ConA0 & 0 & 0 & 0 & 0 & $P=1$ \\
\hline & ConA5 & 0 & 0 & 0 & 0 & $P=1$ \\
\hline \multirow[t]{2}{*}{16 dpi } & ConAO & 0 & $24.0 \pm 53.66$ & 0 & 0 & $\begin{array}{l}H=3.00 \\
d f=3 \\
P=0.39\end{array}$ \\
\hline & ConA5 & 0 & 0 & 0 & 0 & $P=1$ \\
\hline \multirow[t]{2}{*}{$24 \mathrm{dpi}$} & ConAO & 0 & 0 & 0 & 0 & $P=1$ \\
\hline & ConA5 & $594.21 \pm 772.32^{9}$ & 0 & $939.29 \pm 768.24^{g}$ & $546.31 \pm 738.50$ & $\begin{array}{l}H=8.80 \\
d f=3 \\
P=0.03\end{array}$ \\
\hline
\end{tabular}

${ }^{a} P \leq 0.02$ for the significance of difference A vs AS (Mann-Whitney $U$-test, $U=22.5$ )

${ }^{\mathrm{b}} P \leq 0.05$ for the significance of difference A vs $C$ (Mann-Whitney U-test, $U=22$ )

${ }^{c} P \leq 0.01$ for the significance of difference A vs AS (Mann-Whitney U-test, $U=16$ )

${ }^{\mathrm{d}} P \leq 0.01$ for the significance of difference AS vs CS (Mann-Whitney U-test, $U=25$ )

${ }^{\mathrm{e}} P \leq 0.02$ for the significance of difference A vs $C$ (Mann-Whitney U-test, $U=22.5$ )

${ }^{\mathrm{f}} P \leq 0.05$ for the significance of difference A vs $C$ (Mann-Whitney U-test, $U=13.5$ )

${ }^{g} P \leq 0.05$ for the significance of difference A vs AS (Mann-Whitney U-test, $U=11$ )

Abbreviations: Group A, immunocompetent infected group; Group C, immunocompetent control group; Group AS immunosuppressed infected group; Group CS,

immunosuppressed non-infected group; AM, arithmetic mean; SD, standard deviation

cavity is one of the indicators of the intensity of peritonitis and may also result from increased cell proliferation [22]. In protozoan parasites, e.g. Plasmodium spp., Trypanosoma spp., Leishmania spp., and Cryptosporidium parvum infections, splenomegaly is usually observed, and splenic tissue is a good indicator of immunological activity and parasitic infection in mammals [23]. Gornik \& Kuźna-Grygiel [24], in experimental studies on the infection of Acanthamoeba spp., observed that the spleen of the infected mice did not differ from the control in the macroscopic view, which coincides with our results. Moreover, in Acanthamoeba spp. infected spleens, hyperplasia of the white pulp around the arteriolae was found [24].

Knowledge of haematological parameters in mice experimentally infected with Acanthamoeba spp. is extremely limited, while in patients with brain, lung, or peritonitis, Acanthamoeba spp. infections are very diverse. We observed higher lymphocyte and basophile counts in Acanthamoeba spp. infected immunosuppressed mice than in the control. Moreover, monocyte levels were lower in Acanthamoeba spp. infected immunocompetent mice than in infected animals with low immunity. Free-living amoeba also induced an increase in platelet count in infected immunocompetent hosts. Data from a previous clinical study showed a reduction in platelets and lymphocytes in a patient with low immunity and Acanthamoeba pneumonia [25]. In patients with GAE, there was anaemia, upregulation of leukocytes, stable level of lymphocytes and increased or stable level of platelets $[13,26]$.
In the early phase of inflammation, phagocytes produce pro-inflammatory cytokines IL-6, IL-8, IL-17 and IFN- $\gamma$ that can initiate, exacerbate, and maintain the inflammatory process [27]. Antagonistic groups are anti-inflammatory cytokines, including IL-4, produced by Th2 cells that may inhibit the inflammatory process. The roles of IL-4, IL-10, IL-17 and IFN- $\gamma$, in Acanthamoeba spp. pathogenesis are poorly documented. Interleukin- 4 is involved in allergic and autoimmune processes [28]. IL-10 acts as an inhibitor of the immune response, blocking the production of Th1-stimulated lymphocytes and stopping the production of inflammatory cytokines, such as IFN- $\gamma$, as well as inhibiting IL-4 production by Th2 cells [29, 30]. Many studies on pathogenic protozoa indicate that intracellular Leishmania spp., Plasmodium spp., and Trypanosoma cruzi trigger IL-10, but mechanisms involved in this immune event are still unclear [31-33]. Mattana et al. [34] observed that Acanthamoeba trophozoites could induce the production of IL-10 by human mononuclear cells in vitro. In this study, we noticed that IL-4 and IL-10 was significantly downregulated in the Acanthamoeba spp. infected immunosuppressed mice $v s$ immunocompetent infected mice at $16 \mathrm{dpi}$ following higher doses of ConA. The host's immune system may have induced secretion of IL-10 in this study as a response to the infection by Acanthamoeba spp. Moreover, we found relatively low levels of IL-4 after administration of different doses of ConA except at $16 \mathrm{dpi}$ and in immunocompetent infected mice. In Acanthamoeba keratitis, Suryawanshi et al. [35] found an increased production of IL-4, IFN- $\gamma$ and IL-17A and suggested induction of Th1, Th2, and Th17 cell response in the cornea infection. 
Table 4 Immunophenotyping results in \% (spleen) of Acanthamoeba spp.-infected immunosuppressed mice and control mice with low immunity

\begin{tabular}{|c|c|c|c|c|c|}
\hline Parameter/group & & & $\begin{array}{l}\text { Group AS } \\
(n=10)\end{array}$ & $\begin{array}{l}\text { Group CS } \\
(n=6)\end{array}$ & Mann-Whitney U-test \\
\hline \multirow[t]{9}{*}{ CD3+/CD4+ (T lymphocytes) (\%) } & 8 dpi & $\mathrm{AM} \pm \mathrm{SD}$ & $22.67 \pm 0.13$ & $24.47 \pm 0.09$ & $U=16, P=0.53$ \\
\hline & & Median & 22.87 & 25.57 & \\
\hline & & Range & $18.62-26.69$ & $21.51-26.73$ & \\
\hline & $16 \mathrm{dpi}$ & $\mathrm{AM} \pm \mathrm{SD}$ & $28.87 \pm 0.05$ & $27.51 \pm 0.20$ & $U=15, P=0.09$ \\
\hline & & Median & 25.09 & 25.78 & \\
\hline & & Range & $23.11-26.19$ & $22.27-36.82$ & \\
\hline & $24 \mathrm{dpi}$ & $A M \pm S D$ & $25.17 \pm 0.43$ & $16.68 \pm 0.18$ & $U=21, P=0.05$ \\
\hline & & Median & 22.17 & 17.35 & \\
\hline & & Range & $14.67-43.74$ & $12.04-20.34$ & \\
\hline \multirow[t]{9}{*}{ CD3+/CD8+ (\%) } & $8 \mathrm{dpi}$ & $A M \pm S D$ & $5.25 \pm 0.14$ & $6.16 \pm 0.37$ & $U=14, P=0.83$ \\
\hline & & Median & 5.21 & 6.03 & \\
\hline & & Range & $4.44-6.28$ & $4.23-9.89$ & \\
\hline & $16 \mathrm{dpi}$ & $\mathrm{AM} \pm \mathrm{SD}$ & $7.40 \pm 0.05$ & $4.55 \pm 0.24$ & $U=25, P=0.01$ \\
\hline & & Median & 7.51 & 4.19 & \\
\hline & & Range & $6.83-7.94$ & $3.39-6.36$ & \\
\hline & $24 \mathrm{dpi}$ & $\mathrm{AM} \pm \mathrm{SD}$ & $4.23 \pm 0.60$ & $4.10 \pm 0.17$ & $U=19, P=0.21$ \\
\hline & & Median & 5.54 & 3.83 & \\
\hline & & Range & $0.05-7.45$ & $3.35-5.16$ & \\
\hline \multirow[t]{9}{*}{ CD3+/CD4+/CD8+ (DP \%) } & $8 \mathrm{dpi}$ & $A M \pm S D$ & $1.13 \pm 0.19$ & $1.82 \pm 0.29$ & $U=21, P=0.09$ \\
\hline & & Median & 1.18 & 1.87 & \\
\hline & & Range & $0.83-1.35$ & $0.96-2.36$ & \\
\hline & $16 \mathrm{dpi}$ & $\mathrm{AM} \pm \mathrm{SD}$ & $1.52 \pm 0.24$ & $1.61 \pm 0.38$ & $U=13, P=0.99$ \\
\hline & & Median & 1.66 & 1.61 & \\
\hline & & Range & $0.98-1.94$ & $1.17-2.6$ & \\
\hline & $24 \mathrm{dpi}$ & $\mathrm{AM} \pm \mathrm{SD}$ & $2.71 \pm 0.89$ & $1.32 \pm 0.35$ & $U=19, P=0.03$ \\
\hline & & Median & 1.63 & 1.07 & \\
\hline & & Range & $1.1-7.47$ & $0.96-2.03$ & \\
\hline \multirow[t]{9}{*}{ CD3+/CD4-/CD8- (DN \%) } & $8 \mathrm{dpi}$ & $\mathrm{AM} \pm \mathrm{SD}$ & $0.12 \pm 0.21$ & $0.21 \pm 0.18$ & $U=24, P=0.02$ \\
\hline & & Median & 0.12 & 0.23 & \\
\hline & & Range & $0.1-0.16$ & $0.16-0.24$ & \\
\hline & $16 \mathrm{dpi}$ & $\mathrm{AM} \pm \mathrm{SD}$ & $0.14 \pm 0.10$ & $0.09 \pm 0.65$ & $U=20, P=0.14$ \\
\hline & & Median & 0.14 & 0.09 & \\
\hline & & Range & $0.11-0.17$ & $0.03-0.18$ & \\
\hline & $24 \mathrm{dpi}$ & $\mathrm{AM} \pm \mathrm{SD}$ & $0.16 \pm 0.59$ & $0.11 \pm 0.26$ & $U=19, P=0.15$ \\
\hline & & Median & 0.22 & 0.11 & \\
\hline & & Range & $0.004-0.24$ & $0.07-0.13$ & \\
\hline
\end{tabular}

Abbreviations: Group A, immunocompetent infected group; Group C, immunocompetent control group; Group AS immunosuppressed infected group; Group CS, immunosuppressed non-infected group; AM, arithmetic mean; SD, standard deviation DP, CD3+/CD4+/CD8+ double-positive T cells; DN, CD3+CD4-CD8- doublepositive T cells

Interleukin-17A plays a key role in anti-microbial and anti-fungal defence by inducing cytokines, chemokines that affect neutrophil activation [36, 37]. Some studies have demonstrated that IL-17 cells mediate host defences against Chagas disease, mucocutaneous leishmaniasis, alveolar disease and opportunistic infections such as pneumocystosis, toxoplasmosis and cryptosporidiosis [38-42]. IL-17 is also involved in the pathogenesis of autoimmune diseases and transplant rejection reactions of organs [37]. Suryawanshi et al. [35] suggested that IL-17A 
Table 5 The percentage of T lymphocyte sub-populations in the spleen of Acanthamoeba spp.-infected immunosuppressed mice and control mice with low immunity

\begin{tabular}{|c|c|c|c|c|c|}
\hline Parameter/group & & & $\begin{array}{l}\text { Group AS } \\
(n=10)\end{array}$ & $\begin{array}{l}\text { Group CS } \\
(n=6)\end{array}$ & Mann-Whitney U-test \\
\hline \multirow[t]{9}{*}{ CD3+ (T lymphocytes)\% } & $8 \mathrm{dpi}$ & $\mathrm{AM} \pm \mathrm{SD}$ & $29.21 \pm 3.23$ & $33.99 \pm 2.60$ & $U=23, P=0.04$ \\
\hline & & Median & 29.78 & 34.63 & \\
\hline & & Range & $24.75-33.23$ & $30.94-36.46$ & \\
\hline & $16 \mathrm{dpi}$ & $\mathrm{AM} \pm \mathrm{SD}$ & $32.77 \pm 1.62$ & $36.07 \pm 7.97$ & $U=14, P=0.83$ \\
\hline & & Median & 33.03 & 33.63 & \\
\hline & & Range & $30.08-34.27$ & $28.83-49.13$ & \\
\hline & $24 \mathrm{dpi}$ & $\mathrm{AM} \pm \mathrm{SD}$ & $31.65 \pm 11.57$ & $22.96 \pm 3.10$ & $U=22, P=0.05$ \\
\hline & & Median & 28.23 & 22.73 & \\
\hline & & Range & $21.76-51.73$ & $19.78-26.09$ & \\
\hline \multirow[t]{9}{*}{$\mathrm{CD} 4+\%$} & $8 \mathrm{dpi}$ & $\mathrm{AM} \pm \mathrm{SD}$ & $77.37 \pm 1.17$ & $70.74 \pm 1.67$ & $U=25, P=0.01$ \\
\hline & & Median & 77.24 & 70.59 & \\
\hline & & Range & $74.98-79.46$ & $68.14-73.33$ & \\
\hline & $16 \mathrm{dpi}$ & $\mathrm{AM} \pm \mathrm{SD}$ & $74.91 \pm 1.56$ & $77.40 \pm 1.43$ & $U=22, P=0.06$ \\
\hline & & Median & 75.60 & 77.36 & \\
\hline & & Range & $72.70-76.26$ & $75.27-78.73$ & \\
\hline & $24 \mathrm{dpi}$ & $\mathrm{AM} \pm \mathrm{SD}$ & $72.14 \pm 6.06$ & $76.55 \pm 5.98$ & $U=21, P=0.14$ \\
\hline & & Median & 74.18 & 78.70 & \\
\hline & & Range & $62.53-78.17$ & $66.38-81.85$ & \\
\hline \multirow[t]{9}{*}{ CD8+ \% } & $8 \mathrm{dpi}$ & $\mathrm{AM} \pm \mathrm{SD}$ & $17.74 \pm 1.39$ & $21.80 \pm 0.57$ & $U=25, P=0.01$ \\
\hline & & Median & 17.14 & 21.58 & \\
\hline & & Range & $16.14-19.47$ & $21.16-22.62$ & \\
\hline & $16 \mathrm{dpi}$ & $\mathrm{AM} \pm \mathrm{SD}$ & $14.31 \pm 8.43$ & $16.86 \pm 2.67$ & $U=13, P=0.99$ \\
\hline & & Median & 16.72 & 16.40 & \\
\hline & & Range & $0.15-22.62$ & $13.85-20.15$ & \\
\hline & 24 dpi & $\mathrm{AM} \pm \mathrm{SD}$ & $14.98 \pm 2.60$ & $17.89 \pm 1.19$ & $U=21, P=0.09$ \\
\hline & & Median & 14.64 & 17.37 & \\
\hline & & Range & $12.23-18.69$ & $16.93-19.75$ & \\
\hline \multirow[t]{9}{*}{ CD4-/CD8- \% } & $8 \mathrm{dpi}$ & $\mathrm{AM} \pm \mathrm{SD}$ & $3.70 \pm 0.87$ & $5.69 \pm 1.60$ & $U=22, P=0.05$ \\
\hline & & Median & 3.67 & 6.10 & \\
\hline & & Range & $2.62-4.90$ & $3.29-7.18$ & \\
\hline & $16 \mathrm{dpi}$ & $\mathrm{AM} \pm \mathrm{SD}$ & $9.27 \pm 8.06$ & $4.10 \pm 1.22$ & $U=21, P=0.09$ \\
\hline & & Median & 6.67 & 4.48 & \\
\hline & & Range & $4.02-23.5$ & $2.45-5.54$ & \\
\hline & 24 dpi & $\mathrm{AM} \pm \mathrm{SD}$ & $7.22 \pm 3.61$ & $5.97 \pm 2.54$ & $U=17, P=0.41$ \\
\hline & & Median & 6.20 & 4.93 & \\
\hline & & Range & $4.13-13.45$ & $3.81-10.3$ & \\
\hline \multirow[t]{7}{*}{$\mathrm{CD} 4+/ \mathrm{CD} 8+\%$} & $8 \mathrm{dpi}$ & $\mathrm{AM} \pm \mathrm{SD}$ & $0.43 \pm 0.06$ & $0.43 \pm 0.09$ & $U=14, P=0.83$ \\
\hline & & Median & 0.41 & 0.38 & \\
\hline & & Range & $0.36-0.52$ & $0.38-0.61$ & \\
\hline & $16 \mathrm{dpi}$ & $\mathrm{AM} \pm \mathrm{SD}$ & $0.52 \pm 0.29$ & $0.57 \pm 0.13$ & $U=12, P=0.99$ \\
\hline & & Median & 0.65 & 0.58 & \\
\hline & & Range & $0.01-0.70$ & $0.38-0.72$ & \\
\hline & 24 dpi & $\mathrm{AM} \pm \mathrm{SD}$ & $0.34 \pm 0.09$ & $0.48 \pm 0.15$ & $U=19, P=0.21$ \\
\hline
\end{tabular}


Table 5 The percentage of T lymphocyte sub-populations in the spleen of Acanthamoeba spp.-infected immunosuppressed mice and control mice with low immunity (Continued)

\begin{tabular}{lllll}
\hline Parameter/group & & $\begin{array}{l}\text { Group AS } \\
(n=10)\end{array}$ & $\begin{array}{l}\text { Group CS } \\
(n=6)\end{array}$ & Mann-Whitney U-test \\
\hline & Median & 0.38 & 0.44 \\
& Range & $0.21-0.42$ & $0.29-0.67$ \\
\hline
\end{tabular}

Abbreviations: Group A, immunocompetent infected group; Group C, immunocompetent control group; Group AS immunosuppressed infected group; Group CS, immunosuppressed non-infected group; AM, arithmetic mean; SD, standard deviation

production after Acanthamoeba spp. infection plays an important role in host protection against invading parasites in the human cornea (during Acanthamoeba keratitis), although it is not known how it acts as a mediator of systemic inflammatory response, e.g. in amoebic brain and lung infections, and it is not known whether this cytokine participates as a defense mechanism or in the pathogenesis of these diseases. In connection with the multidirectional action of IL-17, it may play a superior role in the cytokine network that regulates immune and inflammatory reactions [39]. In this study, we observed significant expression of IL-17A in Acanthamoeba spp. infected immunocompetent mice compared to control at $16 \mathrm{dpi}$ and there was significant upregulation of this proinflammatory interleukin in the infected mice with low immunity compared to infected immunocompetent hosts after administration of higher doses of ConA. Moreover, the level of IL-17A significantly differed in infected immunocompetent animals $v s$ control mice at $24 \mathrm{dpi}$.

IFN- $\gamma$ is a pro-inflammatory cytokine secreted primarily by $\mathrm{T}$ and natural killer (NK) cells, playing the role of an inducer of adaptive immune responses against protozoan infections [43]. We noticed that IFN- $\gamma$ was blocked at $8 \mathrm{dpi}$ and $16 \mathrm{dpi}$ in all study groups regardless of the immune status of the host. On day 24 post-infection, we observed that the Acanthamoeba spp. infected immunosuppressed mice produced significantly more IFN $-\gamma$ than infected immunocompetent hosts, as in previous studies on the invasion of Blastocystis spp. [44].

Type 1 and 2 cytokines are cross-regulatory groups [45]. Type 1 cytokines (including IFN- $\gamma$ ) favour the development of a strong cellular immune response during parasitic infection whereas type 2 cytokines favour a strong humoral immune response, so IL-4 and IL-10 may decrease the concentration of type 1 cytokines including IFN- $\gamma$, which was observed in Acanthamoeba spp. infection in hosts with normal and low immunity.

Animal models have demonstrated that $\mathrm{T}$ cell response seemed to be crucial for parasite control [46]. Flow cytometry analysis from the spleen of Acanthamoeba spp. infected immunosuppressed mice showed the upregulation of $\mathrm{CD} 3+/ \mathrm{CD} 4+\mathrm{T}$ cells [\%] from the level of the control at $24 \mathrm{dpi}$. Moreover, in the AS group, we found a significant increase in CD3+/CD8+ T cells (\%) at 16 dpi. CD3+CD4-CD8- double-negative (DN) T cells play a key role in regulating the immune responses in transplant rejection, function in graft-versus-host disease, autoimmune diseases and also infectious diseases including parasitic infection $[47,48]$. DN T cells have a regulatory function similar to regulatory $\mathrm{T}$ cells $\left(\mathrm{T}_{\text {regs }}\right)$ and secrete CD4-like cytokines including IL-4, IL-17, IFN- $\gamma$ to exert their T helper function [49]. Liang et al. [50] in HIV positive patients observed that the decrease in DN T cells was correlated with a rapid disease progression. Data from our study shows downregulation of CD3+/CD4-/CD8- T

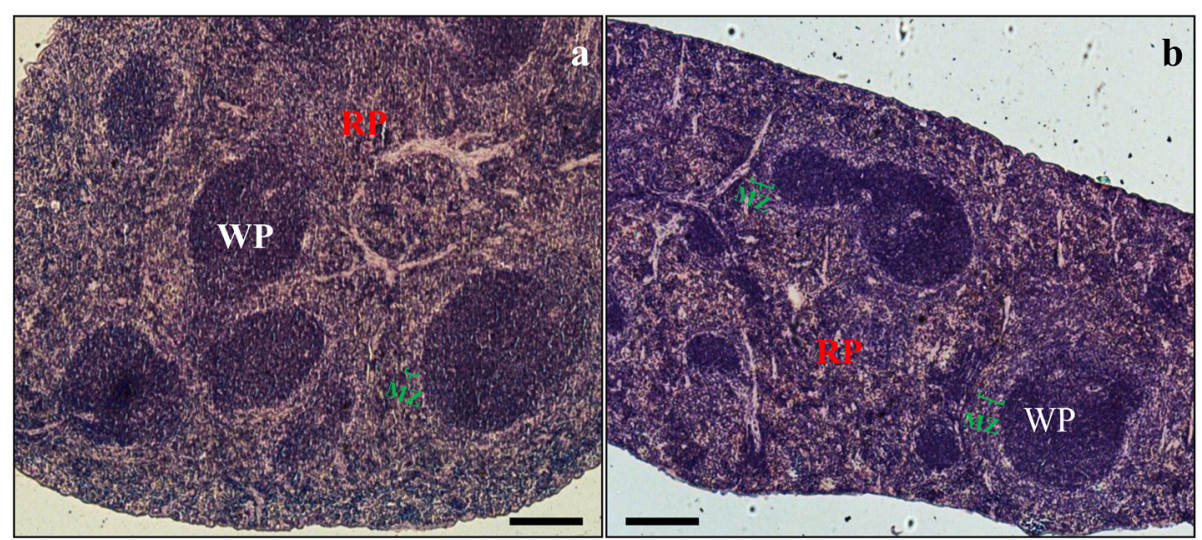

Fig. 2 Morphology of control immunocompetent (a) and immunosuppressed (b) mice spleen. Hematoxylin-eosin staining. Abbreviations: WP, white pulp; RP, red pulp; MZ, marginal zone. Magnification of $\times 50$. Scale-bars: $200 \mu \mathrm{m}$ 


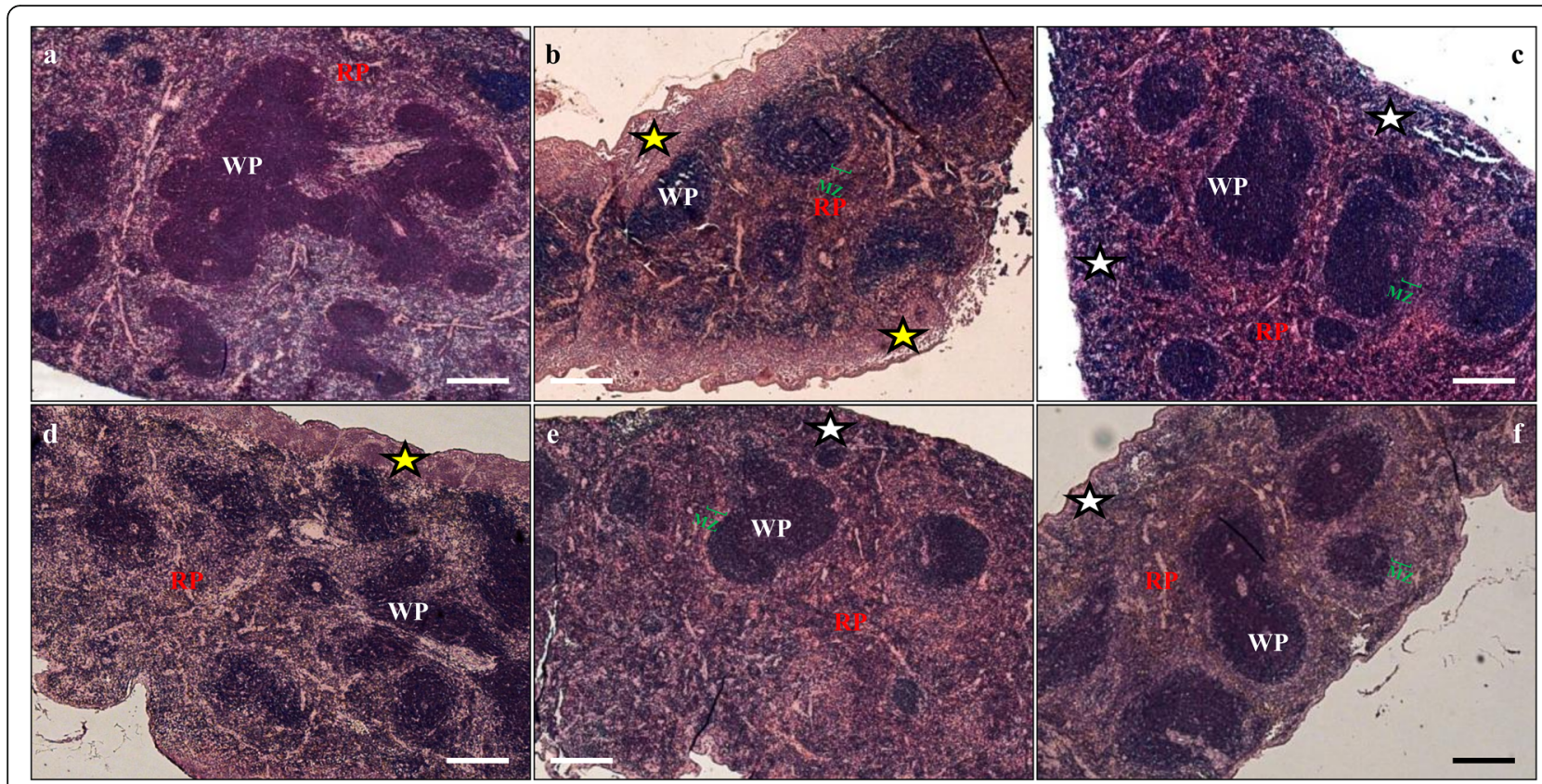

Fig. 3 Representative microphotographs showing spleen histological morphology of mice infected by Acanthamoeba spp. from immunocompetent $(\mathbf{a}-\mathbf{c})$ and $(\mathbf{d}-\mathbf{f})$ with immunosuppressant treatment after $8(\mathbf{a}, \mathbf{d}), 16(\mathbf{b}, \mathbf{e})$ and $24(\mathbf{c}$, $\mathbf{f})$ days post-infection. Hematoxylin-eosin staining. Abbreviations: WP, white pulp; RP, red pulp; MZ, marginal zone. Yellow and white asterisks indicate subcapsular loose or lymphoid infiltrated area. Magnification of $\times 50$. Scale-bars: $200 \mu \mathrm{m}$

cells (\%) in Acanthamoeba spp. infected immunosuppressed mice compared to the control at the beginning of infection. CD3+/CD4+/CD8+ double-positive (DP) T cells have been reported in healthy subjects as well as in patients with autoimmune and chronic infectious diseases [51]. Not much is known about their participation in parasitic invasions but in the Acanthamoeba spp. infected host with low immunity there was an upward trend in the number of DP T cells during the invasion and also a significantly higher DP $\mathrm{T}$ cell count in the AS group compared to $24 \mathrm{dpi}$.

CD3+, CD4+, CD8+ T lymphocytes and CD4+/CD8+ and CD4-/CD8- ratios were also analyzed. In CD3+ $\mathrm{T}$ cells, a significant reduction was observed in infected Acanthamoeba spp. immunosuppressed mice at 8 dpi and a significant peak was observed at $24 \mathrm{dpi}$. CD4+ T cells play a key defensive role during the infection of parasites; they fully activate CD8 $+\mathrm{T}$ cells by destroying infected cells [52]. They are essential for inflammation responses against Toxoplasma gondii infection and also take part in the generation of anti-parasitic immunity and immune surveillance during concomitant immunity [53]. It has been demonstrated that $\mathrm{CD} 8+\mathrm{T}$ cells are essential for protective immunity against the malaria exoerythrocytic cycle in the liver and may play a superior role in the immune response in cutaneous leishmaniasis [54-56]. In Acanthamoeba spp. infected mice with low immunity we observed an increased CD4+ T cell count at $8 \mathrm{dpi}$. The subsequent downward trend of CD4+ T and CD8+ T cells during Acanthamoeba spp. infection may be related to the establishment of the adaptive response to acute infection. Moreover, Gangneux et al. [57] observed that the percentage of CD4+ and CD8+ T cells in the spleen of infected Leishmania infantum mice treated with glucocorticoids did not show statistical differences $v s$ the control group. Immunosuppressive therapy may interfere with the circulation of immune cells, promote apoptosis of lymphoid cells, and induce downregulation of T cells [21]. Moreover, in Acanthamoeba spp. infected immunosuppressed hosts, we observed a statistically significant downregulation and an insignificant upregulation of CD4-/CD8- ratios compared to control at $8 \mathrm{dpi}, 16 \mathrm{dpi}$, and 24 dpi. Acanthamoeba spp. had no significant effect on the $\mathrm{CD} 4+/ \mathrm{CD} 8+$ ratio in immunosuppressed mice during infection.

\section{Conclusions}

We have demonstrated that analysis of the immune response and pathogenesis mechanisms of clinical isolates of Acanthamoeba spp. in an animal model not only has a purely cognitive significance but above all, may help in the development of effective methods of pharmacological therapy. We observed that the Acanthamoeba spp. strain isolated from a patient with AML and with pneumophilic properties affected 
the blood picture in immunocompetent and immunosuppressed mice and induced a change in spleen weight during the infection. Moreover, analysis of anti-inflammatory and pro-inflammatory cytokines produced by splenocytes stimulated with concanavalin A demonstrated that Acanthamoeba spp. induced a selective Th1, Th2 and Th17 response at later stages of the infection in immunocompetent hosts. In the case of hosts with low immunity Acanthamoeba spp. elicited robust Th1 cell-mediated immunity without the participation of Th17. We observed suppression of CD8+ and CD4+ T lymphocytes and DN T lymphocyte populations at the beginning, and in the case of DP T-cell in the final phase of Acanthamoeba spp. infection in hosts with low immunity. Also, CD4+ T lymphocytes and CD3+/CD4+ and $\mathrm{CD} 3+/ \mathrm{CD} 8+$ lymphocyte counts during each stage of acanthamoebiasis were shown to be upregulated. Immunological and immunophenotypic results require further analysis and determination of a broader panel of cytokines including IL-1, IL-2 and IL-6, as well as immunophenotypic studies in immunocompetent hosts.

\begin{abstract}
Abbreviations
A: Immunocompetent Acanthamoeba spp.-infected mice; AIDS: Acquired immune deficiency syndrome; AK: Acanthamoeba keratitis; AM 22: Amoebic strain no. 22; AM: Arithmetic mean; AML: Acute myeloid leukaemia; AS: Immunosuppressed Acanthamoeba spp. infected mice; BASO: Basophils; C: Immunocompetent uninfected control group mice; CA: Cutaneous acanthamoebiasis; CD: Cluster of differentiation; ConA: Concanavalin A; COX: Cyclooxygenase-1; COX-2: Cyclooxygenase-2; CS: Immunosuppressed uninfected control group mice; DN: Double-negative T cells; DP: Doublepositive T cells; dpi: Days post-infection; EOS: Eosinophils; GAE: Granulomatous amebic encephalitis; HCT: Hematocrit; HGB: Haemoglobin; HIV: Human immunodeficiency virus; IFN- $\gamma$ : Interferon gamma; IgD: Immunoglobulin D; IgM: Immunoglobulin M; IL-1: Interleukin 1; IL-10: Interleukin 10; IL-12: Interleukin 12; IL-17A: Interleukin 17A; IL2: Interleukin 2; IL-4: Interleukin 4; IL-6: Interleukin 6; IL-8: Interleukin 8; K-W test: Kruskal-Wallis test; LYM: Lymphocytes; mAb: Monoclonal antibodies; MONO: Monocytes; MPS: Methylprednisolone sodium succinate; MZ: Marginal zone; NEU: Neutrophils; NK: Natural killer cells; NN: Non-nutrient agar; NS: Difference non-significant; p: Level of significance; PGE: Prostaglandin $E_{2} ;$ PLT: Platelets; RBC: Red blood cells; RP: Red pulp; RPMI: Medium Roswell Park Memorial Institute medium; SD: Standard deviation; Th1: Type $1 \mathrm{~T}$ helper; Th17: Type $17 \mathrm{~T}$ helper; Th2: Type $2 \mathrm{~T}$ helper; TNF: Tumor necrosis factor; Tregs: Regulatory $T$ cells; $T X_{2}$ : Thromboxane $B_{2}$ : WBC: White blood cells; WP: White pulp
\end{abstract}

\section{Acknowledgements}

The authors would like to thank Kama Plichta for assistance in conducting the experiments.

\section{Funding}

This work was supported in part by the research project no. WLBiMI-431-04/ S/12/2017 by Pomeranian Medical University in Szczecin.

\section{Availability of data and materials}

The datasets used and analysed during the current study are available from the corresponding author upon reasonable request.

\section{Authors' contributions}

NLA and DKB conceived and designed the research. NLA and DKB performed the experiments. AKW, IWK, KK, PR, KSP, EP and KL performed laboratory work. NLA, DKB and IWK analyzed the data. NLA and DKB contributed to writing the manuscript. BM, BW and DKB provided scientific supervision of the study. All authors read and approved the final manuscript.

\section{Ethics approval}

The study obtained the consent of the Local Ethics Committee in Szczecin and Poznań (No. 29/2015 of 22 June 2015 and 64/2016 of 09 September 2016). All animal experiments were conducted and handled in strict accordance with good animal practice with the recommendations in the Guide for the Care and Use of Laboratory Animals. (https://grants.nih.gov/grants/olaw/guide-for-thecare-and-use-of-laboratory-animals.pdf).

\section{Consent for publication}

Not applicable.

\section{Competing interests}

The authors declare that they have no competing interests.

\section{Publisher's Note}

Springer Nature remains neutral with regard to jurisdictional claims in published maps and institutional affiliations.

\section{Author details}

'Department of Biology and Medical Parasitology, Pomeranian Medical University in Szczecin, 70-204 Szczecin, Poland. ${ }^{2}$ Department of Histology and Embryology, Pomeranian Medical University in Szczecin, 70-204 Szczecin, Poland. ${ }^{3}$ Department of Microbiology, Immunology and Laboratory Medicine, Pomeranian Medical University in Szczecin, 70-204 Szczecin, Poland. ${ }^{4}$ Department of General Pathology, Pomeranian Medical University in Szczecin, 70-204 Szczecin, Poland.

Received: 10 May 2018 Accepted: 11 September 2018

Published online: 20 September 2018

\section{References}

1. Khan NA. Acanthamoeba: biology and increasing importance in human health. FEMS Microbiol Rev. 2006;30:564-95.

2. Siddiqui R, Emes R, Eisheikha H, Khan N. How do Acanthamoeba invade the central nervous system? Trends Parasitol. 2012;27:185-9.

3. Coven SL, Song E, Steward S, Pierson CR, Cope JR, Ali IK, et al. Acanthamoeba granulomatous amoebic encephalitis after pediatric hematopoietic stem cell transplant. Pediatr Transplant. 2017;21:e13060.

4. Evering $T$, Weiss $L M$. The immunology of parasite infections in immunocompromised hosts. Parasite Immunol. 2006;28:549-65.

5. Lanocha N, Kosik-Bogacka D, Maciejewska A, Sawczuk M, Wilk A, KuźnaGrygiel W. The occurrence Acanthamoeba (free-living amoeba) in environmental and respiratory samples in Poland. Acta Protozool. 2009; 48:271-9.

6. Lorenzo-Morales J, Khan NA, Walochnik J. An update on Acanthamoeba keratitis: diagnosis, pathogenesis and treatment. Parasite. 2015;22:10.

7. Jager BV, Stamm WP. Brain abscesses caused by free-living amoeba probably of the genus Hartmannella in a patient with Hodgkin's disease. Lancet. 1972;23:1343-5.

8. Walochnik J, Scheikl U, Haller-Schober EM. Twenty years of Acanthamoeba diagnostics in Austria. J Eukaryot Microbiol. 2015;62:3-11.

9. Morrison AO, Morris R, Shannon A, Lauer SR, Guarner J, Kraft CS. Disseminated Acanthamoeba infection presenting with cutaneous lesions in an immunocompromised patient: a case report, review of histomorphologic findings, and potential diagnostic pitfalls. Am J Clin Pathol. 2016;145:266-70.

10. Marciano-Cabral F, Cabral G. Acanthamoeba spp. as agents of disease in humans. Clin Microbiol Rev. 2003;16:273-307.

11. Omaña-Molina M, Vanzzini-Zago V, Hernandez-Martinez D, Gonzalez-Robles A, Salazar-Villatoro L, Ramirez-Flores E, et al. Acanthamoeba genotypes T3 and T4 as causative agents of amoebic keratitis in Mexico. Parasitol Res. 2016;115:873-8.

12. Cano A, Mattana A, Woods S, Henriquez FL, Alexander J, Roberts CW. Acanthamoeba activates macrophages predominantly through Toll-like receptor 4-and MyD88-dependent mechanisms to induce interleukin-12 (IL-12) and IL-6. Infect Immun. 2017;85:e01054-16.

13. Bloch KC, Schuster FL. Inability to make a premortem diagnosis of Acanthamoeba species infection in a patient with fatal granulomatous amebic encephalitis. J Clin Microbiol. 2005;43:3003-6.

14. Benedetto N, Auriault C. Complex network of cytokines activating murine microglial cell activity against Acanthamoeba castellani. Eur Cytokine Netw. 2002;13:351-7. 
15. Dudley R, Alsam S, Khan NA. The role of proteases in the differentiation of Acanthamoeba castellanii. FEMS Microbiol Lett. 2008;286:9-15.

16. Łanocha-Arendarczyk N, Baranowska-Bosiacka I, Kot K, Gutowska I, Kolasa-Wołosiuk A, Chlubek D, et al. Expression and activity of COX-1. and COX-2 in Acanthamoeba spp.-infected lungs according to the host immunological status. Int J Mol Sci. 2018;19:121.

17. Markowitz SM, Sobieski T, Martinez AJ, Duma RJ. Experimental Acanthamoeba infections in mice pretreated with methylprednisolone or tetracycline. Am J Pathol. 1978;92:733-44.

18. Kosik-Bogacka DI, Baranowska-Bosiacka I, Salamatin R. Hymenolepis diminuta: Effect of infection on ion transport in colon and blood picture of rats. Exp Parasitol. 2010;124:285-94.

19. Kabat-Koperska J, Kolasa-Wołosiuk A, Wojciuk B, Wojciechowska-Koszko I Roszkowska P, Krasnodębska-Szponder B, et al. Changes in the immune system of female wistar rats after exposure to immunosuppressive treatment during pregnancy. Scand J Immunol. 2016;83:418-26.

20. Van Rees EP, Sminia T, Dijkstra CD. Structure and development of the lymphoid organs. In: Mohr U, Dungworth DL, Capen CC, Carlton WW, Sundbergand JP, Ward JM, editors. Pathobiology of the Aging Mouse. Washington: ILSI Press; 1996.

21. Machado JGI, Hoffmann JLI, Krause VLKI, da Silva AVI, Dias-Melicio LAll, Langoni HI. Cell-mediated immune response to Leishmania chagasi experimental infection of BALB/C immunosuppressed mice. J Venom Anim Toxins Incl Trop Dis. 2010;16:131-46.

22. Jansen PL. Spontaneous bacterial peritonitis. Detection, treatment and prophylaxis in patients with liver cirrhosis. Neth J Med. 1997;51:123-8.

23. Schulte-Hostedde AI, Elsasser SC. Spleen mass, body condition, and parasite load in male American mink (Neovison vison). J Mammal. 2011;92:221-6.

24. Górnik K, Kuźna-Grygiel W. Histological studies of selected organs of mice experimentally infected with Acanthamoeba spp. Folia Morphol. 2005;64:161-7.

25. Im K, Kim DS. Acanthamoebiasis in Korea: two new cases with clinical cases review. Yonsei Med J. 1998:39:478-84.

26. Zamora A, Henderson H, Swiatlo E. Acanthamoeba encephalitis: a case report and review of therapy. Surg Neurol Int. 2014;5:68.

27. Wang WY, Tan MS, Yu JT, Tan L. Role of pro-inflammatory cytokines released from microglia in Alzheimer's disease. Ann Transl Med. 2015;3:136.

28. Gulati K, Guhathakurta S, Joshi J, Rai N, Ray A. Cytokines and their role in health and disease: a brief overview. MOJ Immunol. 2016;4:00121.

29. Singh RR. IL-4 and many roads to lupus-like autoimmunity. Clin Immunol. 2003;108:73-9.

30. Mosser DM, Zhang X. Interleukin-10: new perspectives on an old cytokine. Immunol Rev. 2008:226:205-18.

31. Anderson CF, Mendez S, Sack DL. Nonhealing infection despite Th1 polarisation produced by a strain of Leishmania major in C57BL/6 mice. J Immunol. 2005;174:2934-41.

32. Wu YQH, Wang L, Zheng H, Feng J, Liu SH, Cao YM. Plasmodium yoelii: distinct $C D 4 C D 25$ regulatory $T$ cell responses during the early stages of infection in susceptible and resistant mice. Exp Parasitol. 2007;115:301-4.

33. Loevenich K, Ueffing K, Abel S, Hose M, Matuschewski K, Westendorf AM, et al. DC-derived IL-10 modulates pro-inflammatory cytokine production and promotes induction of CD4(+)lL-10(+) regulatory T cells during Plasmodium yoelii infection. Front Immunol. 2017;28:152.

34. Mattana A, Sanna M, Cano A, Delogu G, Erre G, Roberts CW, et al. Acanthamoeba castellanii genotype T4 stimulates the production of interleukin-10 as well as proinflammatory cytokines in THP-1 cells, human peripheral blood mononuclear cells, and human monocyte-derived macrophages. Infect Immun. 2016;84:2953-62.

35. Suryawanshi A, Cao Z, Sampson JF, Panjwani N. IL-17A-mediated protection against Acanthamoeba keratitis. J Immunol. 2015;194:650-63.

36. Cortvrindt C, Speeckaert R, Moerman A, Delanghe JR, Speeckaert MM. The role of interleukin-17A in the pathogenesis of kidney diseases. Pathology. 2017:49:247-58

37. Kuwabara T, Ishikawa F, Kondo M, Kakiuchi T. The role of IL-17 and related cytokines in inflammatory autoimmune diseases. Mediators Inflamm. 2017; 2017:3908061

38. Erdmann H, Roßnagel C, Böhme J, Iwakura Y, Jacobs T, Schaible UE, et al. IL$17 \mathrm{~A}$ promotes macrophage effector mechanisms against Trypanosoma cruzi by trapping parasites in the endolysosomal compartment. Immunobiology. 2013;218:910-23.

39. Das S, Khader S. Yin and yang of interleukin-17 in host immunity to infection. F1000Res. 2017;6:741.
40. de Oliveira $\mathrm{Cl}$, Brodskyn $\mathrm{Cl}$. The immunobiology of Leishmania braziliensis infection. Front Immunol. 2012;3:145.

41. Mezioug D, Touil-Boukoffa C. Interleukin-17A correlates with interleukin-6 production in human cystic echinococcosis: a possible involvement of IL17A in immunoprotection against Echinococcus granulosus infection. Eur Cytokine Netw. 2012;23:112-9.

42. Silva JL, Rezende-Oliveira K, da Silva MV, Gómez-Hernández C, Peghini BC, Silva NM, et al. IL-17-expressing CD4 ${ }^{+}$and $C D 8^{+}$T lymphocytes in human toxoplasmosis. Mediators Inflamm. 2014;2014:573825.

43. Silva-Barrios S, Stäger S. Protozoan parasites and type I IFNs. Front Immunol. 2017:8:14

44. Abdel-Hafeez EH, Ahmad AK, Abdelgelil NH, Abdellatif MZ, Kamal AM, Hassanin KM, et al. Immunopathological assessments of human Blastocystis spp. in experimentally infected immunocompetent and immunosuppressed mice. Parasitol Res. 2016;115:2061-71.

45. Lucey DR, Clerici M, Shearer GM. Type 1 and type 2 cytokine dysregulation in human infectious, neoplastic, and inflammatory diseases. Clin Microbiol Rev. 1996;9:532-62.

46. Padilla AM, Bustamante JM, Tarleton RL. CD8+ T cells in Trypanosoma cruzi infection. Curr Opin Immunol. 2009;21:385-90.

47. Thomson CW, Lee BP, Zhang L. Double-negative regulatory T cells: nonconventional regulators. Immunol Res. 2006:35:163-78.

48. Villani FN, Rocha MO, Nunes Mdo C, Antonelli LR, Magalhães LM, dos Santos $J S$, et al. Trypanosoma cruzi-induced activation of functionally distinct a $\beta$ and $\gamma \delta$ CD4- CD8- T cells in individuals with polar forms of Chagas disease. Infect Immun. 2010;78:4421-30.

49. Vinton C, Klatt NR, Harris LD, Briant JA, Sanders-Beer BE, Herbert R, et al. CD4-like immunological function by CD4- T cells in multiple natural hosts of simian immunodeficiency virus. J Virol. 2011;85:8702-8.

50. Liang Q, Jiao Y, Zhang T, Wang R, Li W, Zhang H, et al. Double negative (DN) $\left[\mathrm{CD3}^{+} \mathrm{CD} 4^{-} \mathrm{CD} 8\right] \mathrm{T}$ cells correlate with disease progression during HIV infection. Immunol Invest. 2013;42:431-7.

51. Giraldo NA, Bolaños NI, Cuellar A, Guzman F, Uribe AM, Bedoya A, et al. Increased CD4+/CD8+ double-positive T cells in chronic Chagasic patients. PLoS Negl Trop Dis. 2011;5:e1294.

52. Engwerda CR, Ng SS, Bunn PT. The regulation of CD4(+) T cell responses during protozoan infections. Front Immunol. 2014;13(5):498.

53. Sacks DL. Vaccines against tropical parasitic diseases: a persisting answer to a persisting problem. Nat Immunol. 2014;15:403-510.

54. Kumar V, Rakha A, Saroa R, Bagai U. CD4+T cells expansion in P. berghei (NK65) infected and immunized BALB/C Mice. J Clin Exp Pathol. 2015;5:229.

55. Ferraz R, Cunha CF, Pimentel MIF, Lyra MR, Pereira-Da-Silva T, Schubach AO, et al. CD3(+)CD4(neg)CD8(neg) (double negative) T lymphocytes and NKT cells as the main cytotoxic-related-CD107a(+) cells in lesions of cutaneous leishmaniasis caused by Leishmania (Viannia) braziliensis. Parasit Vectors. 2017;10:219

56. Bueno LL, Morais CG, Lacerda MV, Fujiwara RT, Braga EM. Interleukin17producing T helper cells are increased during natural Plasmodium vivax infection. Acta Trop. 2012;123:53-7.

57. Gangneux JP, Chau F, Sulahian A, Derouin F, Garin YJ. Effects of immunosuppressive therapy on murine Leishmania infantum visceral leishmaniasis. Eur Cytokine Netw. 1999;10:557-9.

Ready to submit your research? Choose BMC and benefit from:

- fast, convenient online submission

- thorough peer review by experienced researchers in your field

- rapid publication on acceptance

- support for research data, including large and complex data types

- gold Open Access which fosters wider collaboration and increased citations

- maximum visibility for your research: over $100 \mathrm{M}$ website views per year

At $\mathrm{BMC}$, research is always in progress.

Learn more biomedcentral.com/submissions 